\title{
Mechanisch-physiologische
}

\section{Theorie der Abstammungslehre.}

Von

C. v. Nägeli.

Mit einem Anhang:

1. Die Schranken der naturwissenschaftlichen Erkenntniss,

2. Kräfte und Gestaltungen im molecularen Gebiet,

München und Leipzig.

Drack und Verlag von R. Oldenbourg. 1884. 
